\title{
Pomen likovnega branja ilustracije pri interpretaciji leposlovnega besedila ${ }^{14}$
}

JANJA Batič ${ }^{\star 15}$ In Dragica Haramija ${ }^{16}$

$\propto$ Avtorici predstavljata izsledke raziskave o vlogi ilustracije pri interpretiranju leposlovnega besedila. V raziskavo sta vključili študente razrednega pouka in predšolske vzgoje, ki so ob pesmi Nika Grafenauerja Učenjak odgovarjali na vprašanja o značaju in videzu lirskega subjekta, književnem prostoru idr. Prva skupina anketiranih je odgovarjala ob pesmi z ilustracijo Lidije Osterc, druga pa ob pesmi z ilustracijo Marjana Mančka. Rezultati so pokazali, da ilustracija bistveno spreminja sporočilo besedila, predvsem kadar ilustrator z upodobitvijo okolja (ki v pesmi ni eksplicitno določeno) dodaja kontekst. Rezultati kažejo na nujnost celostnega branja ilustriranih besedil, saj je interakcija med besedilom in ilustracijo tista, ki podaja ključne informacije za razumevanje sporočila literarnega dela.

Ključne besede: slikanice, ilustracije, celostno branje (interakcija), Grafenauer, Manček, Osterc, Pedenjped 


\section{Uvod}

Prostor za likovno umetnost je $\mathrm{v}$ osnovnošolskem izobraževanju v Sloveniji običajno omejen na predmet, ki je trenutno poimenovan Likovna umetnost, čeprav je bistvo predmeta v likovni vzgoji. Kljub aktualnemu neposrečenemu poimenovanju predmeta moramo premisliti o vlogi likovne umetnosti, ne le pri poučevanju predmeta likovna umetnost, kjer je ta povezava jasno vzpostavljena, temveč predvsem pri poučevanju vsebin pri drugih predmetnih področjih. Likovna umetnost je namreč lahko izhodišče za učinkovito poučevanje vsebin različnih predmetnih področij, kar zelo učinkovito na praktičnih primerih predstavlja Karen Hosack Jansen. Raziskovalka likovno delo postavi kot temelj za medpredmetni likovni projekt, pri čemer proces njegove zasnove opiše takole (Hosack Jansen, 2014, str. 76): »Ko ste se odločili, katera znanja in spretnosti likovne umetnosti želite učiti v projektu, vključno $s$ prenosljivimi ključnimi spretnostmi, morate razmisliti, katero likovno delo ali dela bi bila ustrezna spodbuda (ob predpostavki, da lahko zagotovite visoko kakovostne reprodukcije) in katera druga predmetna področja bi lahko poučevali pod tem tematskim sklopom.« To je eden od načinov, kako uporabiti ali bolje vključiti likovno umetnost $\mathrm{v}$ različna predmetna področja.

Pogosto pozabljamo ali spregledamo, da se učenci srečujejo z likovnimi deli vedno, ko pri pouku slovenščine obravnavajo leposlovno besedilo, ki je ilustrirano (slikanica, ilustrirana knjiga). Kriteriji izbora obravnavanega dela so pogosto izključno literarni, prav tako pa poteka tudi analiza obravnavanega dela na ravni besedila. Ilustracija je razumljena kot osvetlitev in dodatek, ne pa kot sestavni del izbrane knjige. Obdajajo nas številne vizualne podobe, tako je slikovna informacija prevzela osrednjo vlogo nosilca informacij, zato se moramo vprašati, ali je takšna obravnava ilustriranih leposlovnih besedil še vedno primerna. Perry Nodelman je že leta 1988 pojasnil razmerje med besedilom in ilustracijo ter ju postavil v enakovreden položaj (Nodelman, 1988, str. 221): „Ker besede in slike komunicirajo vsaka s svojimi vrstami informacij in ker skupaj določajo pomene ene drugim, je nujno njihovo ujemanje; komplementarnost med besedami in slikami je namreč odvisna od razlik, ki zaradi drugačnosti dopolnjujejo druga drugo. Rezultat je zveza med sliko in besedo v slikanicah, ki je ironična: vsaka namreč govori o tem, o čemer druga molči."

Raziskovalci (npr. Sipe, 1998; Nikolajeva, 2003) so največ pozornosti odnosu med besedilom in sliko namenili znotraj proučevanja slikanic, ki so posebna oblika multimodalnih knjig. Slikanice imajo namreč »tri pomembne sestavine: besedilo, ilustracije in vsebinsko-oblikovni odnos med besedilom in ilustracijo« (Haramija \& Batič, 2013, str. 23). Za proučevanje je še posebej 
zanimiv vsebinski odnos oziroma interakcija. Sipe (1988, str. 97) pravi, da je »/.../ odnos med dvema vrstama besedila - verbalnim in vizualnim besedilom zapleten in subtilen«. Odnos označi tudi kot sinergijski, saj »/.../ končni učinek ni odvisen samo od zveze besedila in ilustracije, ampak tudi na zaznani interakciji ali transakciji med obema deloma.« (Sipe, 1988, str. 98-99). Nikolajeva (2003) identificira tri vrste interakcij: simetrično (besede in slike pripovedujejo isto zgodbo); komplementarno (besede in slike med seboj zapolnjujejo vrzeli); stopnjevano (slike podčrtujejo in presegajo besedilo ali obratno). Stopnjevana interakcija se lahko razvija v dve smeri: kadar je ta razlika velika, se lahko razvije protislovna ali kontrapunktna dinamika (sporočilo presega sporočila obeh ravni komunikacije), v skrajni različici pa gre za nezdružljivo ali kontradiktorno interakcijo (slike in besede tvorijo dvoumno sporočilo, ki zahteva od bralca več miselnega napora). Navedene vrste interakcij lahko opazujemo tudi znotraj posamezne ilustracije in pripadajočega besedila. Zanimivo vprašanje odnosa med besedilom in sliko se pojavi, kadar beremo ilustrirano pesem. V pesniških zbirkah so pesmi in ilustracije pogosto natisnjene tako, da je na eni strani besedilo, na drugi ilustracija, ali pa je besedilo vključeno neposredno v ilustracijo. Slikanica lahko vsebuje eno pesem, pri čemer je besedilo postavljeno tako, da so deli pesmi postavljeni vsak v svojo ilustracijo, kakor npr. v delu Lile Prap Kam gredo sanje (2008). Odnos med sliko in ilustracijo je v navedeni pesmi tako tesen, da si ni mogoče predstavljati interpretacije brez celostnega branja slikanice: literarni lik v besedilu ni omenjen, ilustracija pokaže, da je to deček, ilustracija poda tudi književni prostor, prikaže predmetno stvarnost itd.

Ilustracije lahko v slikanicah spreminjajo razumevanje besedila, in sicer najpogosteje naslednje elemente: književni čas, literarne like, razpoloženje, prostor ter like, predmetno stvarnost in dogodke, ki v besedilu niso omenjeni (Haramija \& Batič, 2013, str. 262-264). Književni čas ilustratorji pogosto določijo z upodobitvijo ure, koledarja, letnega časa. Prav tako o času govori kompozicija. V kulturi, kjer poteka branje od leve proti desni, mnogokrat enačimo odnos levo - desno s časom dogajanja prej - potem. Takšni primeri so še posebej zgovorni, kadar je isti lik upodobljen v eni ilustraciji (npr. dvostranski) dvakrat, saj situacije ne preberemo kot prisotnost dveh enakih likov, temveč kot časovno zaporedje dogodkov, ki govori tudi o gibanju. Nikolajeva pravi (2003, str. 15), da je »/.../najpogostejše in najuspešnejše sredstvo za ponazarjanje gibanja v ilustraciji tako imenovana simultana sukcesija /.../. Gre za zaporedje upodobitev človeške figure v časovno ločenih trenutkih, ki pa jih gledalec dojema kot celoto, ki se dogaja v strogo določenem zaporedju. Spremembe, ki se pojavijo v vsaki naslednji sličici, nakazujejo časovno razliko med prejšnjim in naslednjim prizorom. « Ko Nikolajeva govori o »vsaki naslednji sličici« (prav tam) razumemo, 
da je to sličica, ki je postavljena desno od izhodiščne. Kar je upodobljeno na levi, se je namreč zgodilo prej, kar pa na desni, se dogaja za tem. Literarni liki so v krajših besedilih le poimenovani, ne pa tudi opisani, zato je ilustrator tisti, ki upodobi njihovo zunanjost. Enako je s prostorom. Nikolajeva (2003, str. 11) pravi: »Medtem ko besede prostor lahko le opisujejo, ga ilustracije dejansko kažejo, kar je neprimerno bolj učinkovito. /... / Verbalni pripovedovalec bralca prisili, da določene podrobnosti v prostoru ,opazi', druge pa spregleda. Vizualni prikaz prizorišča je ,nepripoveden' in kot tak nemanipulativen." Hkrati ilustrator s spreminjanjem zornega kota in fokusa usmerja bralčevo/gledalčevo pozornost. Zanimiv ,konflikt' se zgodi, kadar ilustrator osrednji dogodek postavi v drugi plan, v prvega pa dogajanje, ki ga besedilo eksplicitno ne omenja. Več takih primerov je najti v slikanici Juri Muri v Afriki, o fantu, ki se ni maral umivati Toneta Pavčka in Damijana Stepančiča (2012), kjer ilustrator osrednji dogodek $\mathrm{v}$ več ilustracijah prikaže kot delček širšega dogajanja. Kako bo bralec razumel oz. prebral ilustracijo, je odvisno tudi od njegovega razumevanja simbolov, znakov in poznavanja konteksta, pri čemer je treba izpostaviti bralčeve izkušnje, ki vplivajo na njegovo interpretacijo.

Našteti elementi se v prvi vrsti nanašajo na to, kaj je upodobljeno, hkrati pa se že nanašajo tudi na to, kako je upodobljeno (npr. enačenje gibanja s postavitvijo v kompozicijo). Bralčevo poznavanje osnov likovne teorije (likovni elementi, načini likovnega komponiranja itd.), poznavanje značilnosti različnih likovnih tehnik in njihovih izraznih možnosti, predstavlja temeljni pogoj za celostno branje ilustriranega besedila. Jane Doonan izpostavi (1993, str. 8): »Ko otrokom povemo in pokažemo, kako lahko črte, oblike in barve prenašajo ideje in občutke, lahko raziskujejo razsežnosti nad tem, kar je dobesedno podano." To je mogoče le, če gledalce (učence) vzgajamo v likovno občutljive posameznike, ki bodo pri interpretaciji upoštevali, kaj, kako in s kakšnimi likovnimi sredstvi je je v ilustraciji nekaj upodobljeno.

Postavljena teoretična izhodišča so izdelana ob proučevanju slikanic, za katere je značilno veliko število ilustracij, ki pripadajo besedilu. Postavlja se vprašanje, kakšno pripovedno moč ima ena sama ilustracija na besedilo pesmi oz. ali lahko in kako ena ilustracija vpliva na interpretacijo besedila. 


\section{Medtodologija}

Raziskava, ${ }^{17} \mathrm{~s}$ katero smo želeli ugotoviti, kako ilustracija spreminja pomen pesmi, je potekala v mesecu juniju leta 2014. Raziskovalni vzorec je bil priložnostni ( $n=301)$. Vključeni so bili študentje Pedagoške fakultete Univerze v Mariboru, in sicer: smer predšolska vzgoja 146 študentov $(48,5 \%)$ in razredni pouk 155 študentov (51,5\%). Študentje so bili v času poteka raziskave vpisani v naslednje letnike prve stopnje študija: prvi letnik (19,3\%), drugi letnik (37,2\%) in tretji letnik (43,5\%). V raziskavi je sodelovalo 279 žensk (92,7\%) in 22 moških $(7,3 \%)$. Sodelovanje v raziskavi je bilo prostovoljno in anonimno. Študentom smo na platno projicirali ilustrirano pesem Nika Grafenauerja z naslovom Učenjak. Študente, ki so sodelovali v raziskavi, smo razdelili v dve skupini. Prva skupina (56,1\% vseh študentov) je dobila pesem Učenjak z ilustracijo Lidije Osterc (v nadaljevanju Pedenjped A). Druga skupina (43,9\%) je dobila isto pesem, a z ilustracijo Marjana Mančka (v nadaljevanju Pedenjped B). Študente smo prosili, da izpolnijo vprašalnik, ki je vseboval vprašanja odprtega tipa (kakšen je Pedenjped, kakšne knjige bere Pedenjped itd.). Njihove odgovore smo nato združili v kategorije. Dobljene podatke smo analizirali s statističnim programom SPSS in jih obdelali na nivoju deskriptivne statistike (frekvence) in inferenčne statistike (hi-kvadrat preizkus).

Kriteriji za izbor pesmi so literarni (priznan slovenski pesnik Niko Grafenauer) in likovni (pesem sta ilustrirala dva vidna slovenska ilustratorja, Lidija Osterc in Marjan Manček).

Niko Grafenauer (1940) je bil urednik in prevajalec, od leta 2003 je član Slovenske akademije znanosti in umetnosti, piše za odrasle in otroke. V mladinski književnosti je posebej pomembna njegova poezija, napisal pa je tudi dve prozni deli za otroke. ${ }^{18}$ Grafenauer je za svoje literarna dela prejel številne nagrade, posebej velja omeniti Prešernovo nagrado za življenjsko delo (1997) in Levstikovo nagrado za življenjsko delo (2007). V predstavitvi slovenske mladinske književnosti je Marjana Kobe (1996, str. 4) izpostavila: »Sredi 6o. let je Niko Grafenauer (Pedenjped, 1966) segel k izvirom slovenskega umetniškega pesništva za mladino pri Franu Levstiku in napovedal razmah poetik, ki

17 Predstavljena raziskava je del obsežnejše raziskave, ki smo jo izvedli med študenti Univerze v Mariboru, in sicer na Pedagoški fakulteti (smer razredni pouk, predšolska vzgoja in likovna pedagogika) in na Filozofski fakulteti (smer slovenski jezik in književnost). V tem prispevku predstavljamo le odgovore študentov razrednega pouka in predšolske vzgoje, saj imajo ti v učnih načrtih predmete s področja književnosti in likovnega izražanja.

18 Najpomembnejša mladinska dela Nika Grafenauerja so: Skrivnosti (2012 in več izdaj), Žabja radijska postaja (2011), Troje gosk in en gosak (2011), Pedenjped ima spet rep (2010), Špicmožic in Halomuha (2009), V Pedenjpravljico prost vstop (2003), Uganke (2001), Kadar glava nad oblaki plava (2000), Mahajana in druge pravljice o Majhnici (1990), Majhnica (1987), Stara Ljubljana (1983), Lokomotiva, lokomotiva (1981), Nebotičniki, sedite (1980), Avtozaver (1976). 
izhajajo iz teorije igre kot, simbola sveta. /.../ Sočasno sta Niko Grafenauer in Saša Vegri z upesnjevanjem bivanjskih vprašanj odpirala pesništvu za mladino nove razsežnosti.« Igor Saksida v članku Sodobna slovenska mladinska poezija (2006, str. 273) utemeljuje Grafenauerjevo osrednje mesto v pesništvu za otroke v obdobju modernizma. ${ }^{19}$ Nadalje to tezo Saksida izpelje v članku Metodologija interpretacije mladinske književnosti na Slovenskem (Haramija \& Saksida, 2013, str. 185): „Grafenauerjev (1975) esej Igra v pesništvu za otroke še vedno sodi med najpomembnejše prispevke za razumevanje besedilotvornih postopkov kakovostne mladinske poezije oz. književnosti nasploh. Avtor je očrtal razvoj mladinske poezije od njenih začetkov pri Levstiku do sodobnosti in igro (oz. jezikovno inovativnost) določil kot razločujočo potezo kvalitetne (estetsko dozorele) poezije, ki je enakovredna literaturi za odrasle.« V poetiki svojega pesnjenja se avtor drži načel, ki jih prepoznava kot najvišjo kvaliteto pri drugih otroških pesnikih. Močna navezanost na tradicijo poezije Frana Levstika in Otona Župančiča, začetnikov slovenske otroške posvetne poezije ob koncu 19. in začetku 20. stoletja, je vidna tudi v poetiki Grafenauerjeve pesniške zbirke Pedenjped. Zbirka lirske otroške poezije iz leta 1966 je bila najprej izdana z ilustracijami Lidije Osterc, leta 1969 je izšla dopolnjena izdaja, nato pa leta 1979 kot slikanica z izborom pesmi ter ilustracijami Marjana Mančka. Zbirka je med leti 1966 in 2014 izšla kar 17-krat z različnimi izbori pesmi o Pedenjpedu in njihovimi ponatisi. ${ }^{20}$ Pedenjped je splošno prepoznaven literarni lik v slovenski otroški književnosti, katerega popularnost v petdesetih letih od prvega izida ne usahne. Tematsko je zbirka homogena, otroška (torej Pedenjpedova) perspektiva odslikava vsakdan v otrokovem domačem okolju, ki je večinoma povezano $\mathrm{z}$ varnostjo in igro. Grafenauerju je uspelo, in to je temeljna kakovost vseh pesmi o Pedenjpedu, skozi otroško perspektivo in otroška čustva predstaviti svet sodobnega otroka, ki živi v izobilju in miru. To potrjuje tudi pesnikova izjava (Grafenauer, 1969, str. 67): »S Pedenjpedom sem se hotel predvsem približati otroškemu načinu gledanja na stvari in dogodke, s katerimi se otrok srečuje v vsakdanjem življenju, obenem pa svoja lastna otroška doživetja kakor tudi vtise, ki nastajajo v meni, ko danes opazujem otroke, tako združiti med sabo, da bo oseba tega junaka kar najbolj privlačna.« Avtorju je to nedvomno uspelo, zato lahko pesemski vzorec nastaja še danes: avtor torej že petdeset let piše

19 Saksida (2006, str. 271) zapiše: »Za modernistično mladinsko poezijo ključna je estetska igra, ki pa ni le tema pesmi; tako se v njej kažejo naslednje značilnosti: igra kot način oblikovanja besedilne stvarnosti, tj. nelogično povezovanje besed; izmišljanje novih besed in rušenje pravopisnih konvencij; odmik od prikaza človeškega lika (predvsem otroka) $\mathrm{k}$ mnogopomenskemu opisovanju predmetov, delov telesa in bivanjskih pojmov."

20 Pedenjped je doslej (med leti 1966 in 2013) izšel 17-krat, in sicer 15-krat z različnimi izbori pesmi pod naslovom Pedenjped, dvakrat pa pod drugačnim naslovom, in sicer Pedenjped ima spet rep in Možbeseda Pedenjped. 
pesmi o tem vsakdanjem majhnem otroku. Deček je v prvi pesmi z naslovom Pedenjped opisan: oblečen je v pedenjsrajčko, pedenjhlače, je skuštran, ima štrleča ušesa ter jamice na ličkih. Sledijo pesmi o njegovem oblačenju, umivanju, hranjenju, igri ipd. Že v naslovu zbirk vidna morfološka tvorba s prvim delom sklopa pedenj, ${ }^{21}$ ki je oznaka za majhno (srajčko, hlače, čevlje) ali pripadajoče (tvorjeno iz samostalnika: mama, očka; tvorjeno iz glagola: pomoč), ali oboje hkrati (carstvo, slike, brzovlak, postelja), ki ne pomeni zgolj lastnine, ampak tudi funkcijo, npr. pedenjslika ni le majhna slika, temveč hkrati pomeni sliko, ki jo je naslikal Pedenjped. ${ }^{22}$ Zanimiva je raba fraz (npr. biti mož beseda, napokati se kakor boben), in onomatopoetskih izrazov (npr. v Uspavanki trilili, tralala; Brzovlak uuu; največ jih je v pesmi Glasbenik svirili, svirilili, svirilaja in kombinacije).Vse pesmi sodijo v lirsko poezijo, imajo tradicionalno zgradbo s štirivrstičnimi kiticami, s prestopno ali parno zaporedno rimo, avtor skoraj v vsaki pesmi uporabi enjambement in personifikacijo (npr. žlici se preveč mudi), izbrana pesem je po strukturi podobna drugim.

Učenjak

Pedenjped rad prelistava

kupe vseh mogočih knjig.

Glasno bere, prikimava

vsem nazorom brez razlik.

Cele dni se nadnje sklanja,

vsak list zase preštudira.

Glava ga teži od znanja,

da si jo z roko podpira.

Hišni hrup mu ni napoti,

ves čas gode svoj: lalála.

Če pa se pri branju zmoti,

si natakne brž očala.

(Niko Grafenauer, 1966, str. 23)

21 Primer v Slovenskem pravopisu (2001, str. 1086): "pédenj. prvi del sklopa; pédenjčlôvek zelo majhen človek«.

$22 \mathrm{~V}$ pesmi Brzovlak je ves čas jasno, da je Pedenjped pravzaprav pedenjbrzovlak, ki (Grafenauer, 2011, str. 22) "po vseh štirih v noč sopiha /.../ Če pa je hudo zaspan,/ spet postane Pedenjped.« 
Lidija Osterc ${ }^{23}$ (slika 1, Pedenjped A) je besedilo dopolnila z ilustracijo dečka, ki ima košate lase, okrogla očala, kratke hlače, črtaste nogavice in zašiljene čeveljce. Njegove kratke hlače in nogavice spominjajo na oblačilno kulturo prve polovice dvajsetega stoletja. Postavljen je pokončno, v desni roki drži knjigo z naslovom ABECEDA. Knjiga pa je obrnjena na glavo. Prostor ni prikazan, ilustracija je umeščena ob besedilo pesmi. Deček je obrnjen z glavo proti levi strani. Glede na telesne proporce lahko sklepamo, da ne gre za majhnega otroka, temveč za šolarja. Deček v ilustraciji z zanimanjem ,bere` oz. gleda knjigo, a na glavo obrnjene črke na naslovnici knjige, ki jo drži v rokah, govorijo o tem, da ne zna brati. Lidija Osterc je naredila črno belo risbo, ki je postavljena na toniran papir. Naslov pesmi je oblikovan $\mathrm{v}$ beli barvi, besedilo $\mathrm{v}$ črni. Odsotnost kromatičnih barv vzbuja občutenje zadržanosti, resnosti. Iz ilustracije ne dobimo podatkov o tem, kaj je hišni hrup.

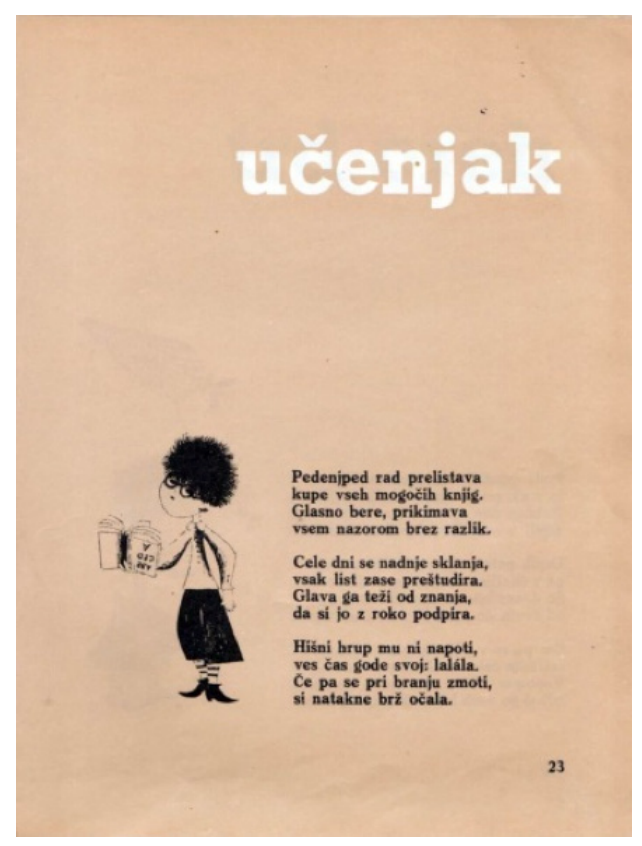

Slika 1. Niko Grafenauer in Lidija Osterc: Pedenjped. Ljubljana: Mladinska knjiga, 1966, str. 23.

23 Lidija Osterc (1928-2006) je diplomirala na Akademiji za likovno umetnost, bila je slikarka in ilustratorka. Za ilustracije je prejela kar trikrat Levstikovo nagrado, in sicer leta $1964 \mathrm{za}$ ilustracije v slikanici Hišica iz Kock Ele Peroci, 1966. leta za ilustracije v knjigah bratov Grimm Lonček, kuhaj! in Sneguljčica in druge Grimmove pravljice ter Frana Milčinskega Desetnica, leta 1969 pa za ilustracije v knjigah Roberta Crotteta Laponske pripovedi, Toneta Pavčka Strašni lovec Bumbum in Ele Peroci Očala tete Bajavaje. 


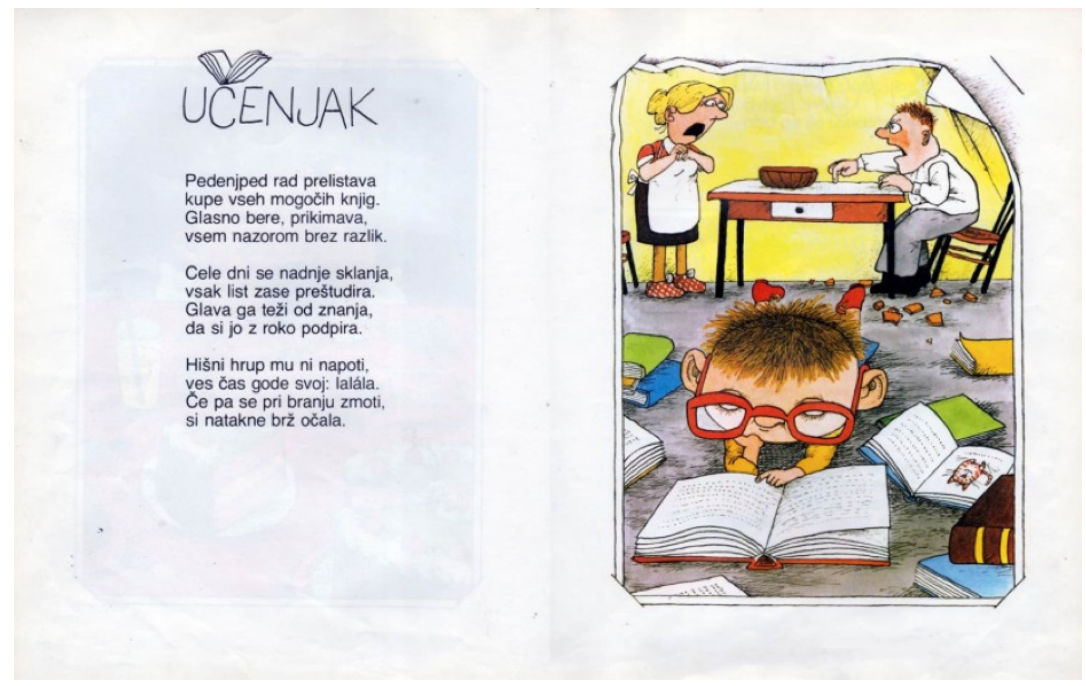

Slika 2. Niko Grafenauer in Marjan Manček: Pednjped. Ljubljana: Mladinska knjiga, 1979, brez paginacije.

Marjan Manček ${ }^{24}$ (slika 2, Pedenjped B) je ilustracijo zasnoval tako, da je v prvi plan postavil Pedenjpeda, dečka z veliko glavo (proporci telesa asociirajo na mlajšega, predšolskega otroka), z velikimi rdečimi očali, rjavimi kuštravimi lasmi, modrimi hlačami in rdečimi čeveljci. Pred seboj ima odprto debelo knjigo. $\mathrm{Z}$ desno roko si podpira glavo, s kazalcem levice se pomika po besedilu. Okrog njega so postavljeni kupi knjig. V eni od odprtih knjig je ilustracija mačke. Prizor je upodobljen iz žabje perspektive, torej od spodaj navzgor. V ozadju je upodobljena miza, na levi strani stoji ženska z ukrivljenimi odprtimi usti in tesno sklenjenimi rokami pred seboj. Na desni strani je upodobljen moški z jeznim izrazom na obrazu, s kazalcem desnice tolče po mizi. Na tleh pod mizo so črepinje. Marjan Manček je izdelal kolorirano risbo, v kateri izstopajo rumena, zelena, modra in rdeča barva. Ilustracija je postavljena v okvir, in sicer je upodobljena kot fotografija v albumu. Po zmečkanem zgornjem robu in izmaknjenem zgornjem desnem vogalu sklepamo, da gre za časovno oddaljen prizor oz. dogodek, ki se je zgodil pred časom, spomin nanj pa je dokumentiran v albumu fotografij. Hkrati pa upodobitev zmečkanega dela ilustracije

24 Marjan Manček (1948) je diplomiral iz angleščine in zgodovine na Filozofski fakulteti, deluje kot svobodni umetnik, ukvarja se predvsem z avtorskimi stripi (npr. Hribci), ilustracijami, karikaturami. Za svoje delo je prejel številne nagrade, s področja mladinske književnosti je najpomembnejša Levstikova nagrada za življenjsko delo leta 2007. Leta 1977 je prejel Levstikovo nagrado za ilustracije zgodbe Josipa Jurčiča Kozlovska sodba v Višnji gori, leta 2009 pa tudi Smrekarjevo priznanje. 
potencira napetost dogodka, ki se odvija za Pedenjpedom. Ilustracija je v slikanici postavljena samostojno na desno stran, na levi se nahaja pesem. Naslov pesmi je oblikovan tako, da je namesto strešice nad črko (亡̌) postavljena odprta knjiga. Mančkova ilustracija poudari svet otroka (žabja perspektiva, močne kromatične barve), izpostavi pomen okolja (družinsko okolje, prisotnost knjig) ter prikaže hišni hrup (prepir staršev ali natančneje: jeznega, agresivnega očeta in prestrašeno mater).

\section{Rezultati in interpretacija}

Najprej nas je zanimalo, kakšen je Pedenjped po značaju. Najpogostejši odgovori študentov so bili: »rad bere ali lista knjige« (45,5\%), »je razgledan, pameten, učen« $(34,9 \%)$, »je radoveden, vedoželjen« $(27,9 \%)$, »se rad uči« $(15,6$ $\%)$, »je nagajiv, navihan, hudomušen « $(14,6 \%)$ in »je priden, ubogljiv otrok« (13,0 \%). Na vprašanje kakšne knjige bere Pedenjped, je največ študentov odgovorilo, da bere "vse vrste oz. različne knjige« $(82,4 \%)$, manjši delež študentov $(24,3 \%)$ je našteval ali opisoval knjige (npr. slikanice, enciklopedije, debele knjige). Na vprašanje ali Pedenjped zares bere, je skoraj tretjina študentov (31,2 \%) odgovorila, da Pedenjped bere, ostali pa so odgovorili, da ne bere zares oz. da se samo pretvarja, da bere.

Analiza je pokazala, da pri odgovorih ni statistično značilnih razlik med študenti, ki so opazovali ilustracijo A (avtorica Lidija Osterc) in tistimi, ki so opazovali ilustracijo B (avtor Marjan Manček).

Pri opisu videza so študentje najpogosteje opazili očala. Kar 68,4 \% jih je zapisalo, da Pedenjped nosi očala. Skoraj polovica vseh študentov je opisovala obliko pričeske in/ali dolžino las (47,5 \%). Kar 38,9 \% vprašanih je zapisalo, da je Pedenjped otrok ali majhen deček. Ostali opisi so se nanašali še na: barvo las $(17,9 \%)$, velikost očal $(11,3 \%)$, opis higienskih navad (neurejen, brez higienskih navad, $8,3 \%)$, opis hlač $(8,0 \%)$, opis majice $(8,0 \%)$, barvo očal $(7,6 \%)$, ušesa (štrleča ali velika ušesa, 6,6 \%), opis velikosti (6,0 \% študentov je zapisalo, da je Pedenjped velik fant), opis čevljev (5,6 \%), opis postave (suha postava, 5,3\%) in opis nogavic $(4,7 \%)$. Rezultate smo analizirali glede na prikazano ilustracijo (A ali B) in ugotovili, da nihče od študentov, ki so ob branju pesmi opazovali ilustracijo Lidije Osterc, ni opisoval barve očal. Nihče od študentov, ki so ob branju opazovali ilustracijo Marjana Mančka, ni zapisal, da je Pedenjped velik fant, prav tako nihče ni opisoval nogavic. Statistično značilne razlike so se pojavile še pri nekaterih drugih odgovorih (tabela 1). 
Tabela 1. Opis videza

\begin{tabular}{|c|c|c|c|c|c|c|c|c|c|}
\hline & & \multicolumn{6}{|c|}{ Ilustracija } & \multirow{2}{*}{\multicolumn{2}{|c|}{$\chi^{2}-$ preizkus }} \\
\hline & & \multicolumn{2}{|c|}{ A - L. Osterc } & \multicolumn{2}{|c|}{ B - M. Manček } & \multicolumn{2}{|c|}{ skupaj } & & \\
\hline & & $\mathrm{f}$ & $\mathrm{f} \%$ & $\mathrm{f}$ & $\mathrm{f} \%$ & $\mathrm{f}$ & $\mathrm{f} \%$ & $\chi^{2}$ & $\mathrm{P}$ \\
\hline \multirow{2}{*}{$\begin{array}{l}\text { Opisovanje velikosti } \\
\text { očal }\end{array}$} & YES & 3 & 1.8 & 31 & 23.5 & 34 & 11.3 & \multirow{2}{*}{34.861} & \multirow{2}{*}{0.000} \\
\hline & $\mathrm{NO}$ & 166 & 98.2 & 101 & 76.5 & 267 & 88.7 & & \\
\hline \multirow{2}{*}{$\begin{array}{l}\text { Opisovanje barve } \\
\text { očal (rdeča) }\end{array}$} & YES & 0 & 0.0 & 23 & 17.4 & 23 & 7.6 & \multirow{2}{*}{31.883} & \multirow{2}{*}{0.000} \\
\hline & NO & 166 & 100.0 & 109 & 82.6 & 278 & 92.4 & & \\
\hline \multirow{2}{*}{$\begin{array}{l}\text { Opisovanje dolžine } \\
\text { las ali oblike pričeske }\end{array}$} & YES & 96 & 56.8 & 47 & 35.6 & 143 & 47.5 & \multirow{2}{*}{13.355} & \multirow{2}{*}{0.000} \\
\hline & NO & 73 & 43.2 & 85 & 64.4 & 158 & 52.5 & & \\
\hline \multirow{2}{*}{ Opisovanje barve las } & YES & 18 & 10.7 & 36 & 27.3 & 54 & 17.9 & \multirow{2}{*}{13.090} & \multirow{2}{*}{0.000} \\
\hline & NO & 151 & 89.3 & 96 & 72.7 & 247 & 82.1 & & \\
\hline \multirow{2}{*}{ Majhen deček, otrok } & YES & 46 & 27.2 & 71 & 53.8 & 117 & 38.9 & \multirow{2}{*}{22.018} & \multirow{2}{*}{0.000} \\
\hline & NO & 123 & 72.8 & 61 & 46.2 & 184 & 61.1 & & \\
\hline \multirow{2}{*}{ Velik fant } & YES & 18 & 10.7 & 0 & 0.0 & 18 & 6.0 & \multirow{2}{*}{14.953} & \multirow{2}{*}{0.000} \\
\hline & NO & 151 & 89.3 & 132 & 100.0 & 283 & 94.0 & & \\
\hline \multirow{2}{*}{$\begin{array}{l}\text { Velika ali štrleča } \\
\text { ušesa }\end{array}$} & YES & 3 & 1.8 & 17 & 12.9 & 20 & 6.6 & \multirow{2}{*}{14.731} & \multirow{2}{*}{0.000} \\
\hline & NO & 166 & 98.2 & 115 & 87.1 & 281 & 93.4 & & \\
\hline \multirow{2}{*}{ Opisovanje hlač } & YES & 22 & 13.0 & 2 & 1.5 & 24 & 8.0 & \multirow{2}{*}{13.364} & \multirow{2}{*}{0.000} \\
\hline & NO & 147 & 87.0 & 130 & 98.5 & 277 & 92.0 & & \\
\hline \multirow{2}{*}{ Opisovanje nogavic } & YES & 14 & 8.3 & 0 & 0.0 & 14 & 4.7 & \multirow{2}{*}{11.468} & \multirow{2}{*}{0.001} \\
\hline & NO & 155 & 91.7 & 132 & 100.0 & 287 & 95.3 & & \\
\hline Neurejen, brez & YES & 19 & 11.2 & 6 & 4.5 & 25 & 8.3 & 4365 & 0,037 \\
\hline higienskih navad & NO & 150 & 88.8 & 126 & 95.5 & 276 & 91.7 & 4.500 & 0.03 \\
\hline & YES & 16 & 9.5 & 0 & 0.0 & 16 & 5.3 & 13199 & 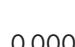 \\
\hline suna pustava & & 153 & 90.5 & 132 & 100.0 & 285 & 94.7 & 10.150 & 0.000 \\
\hline
\end{tabular}

Študentom smo zastavili tudi vprašanje, kaj v pesmi pomeni hišni hrup. Odgovore smo razvrstili v dve skupini, in sicer hrup, ki nastane zaradi prepira, in hrup, ki nastane zaradi različnih zvokov v stanovanju (npr. ropotanje s posodo, zvoki domačih živali). Razlike med odgovori so statistično značilne (tabela 2). 
Tabela 2. Interpretacij pomena »hišni hrup»

\begin{tabular}{|c|c|c|c|c|c|c|c|c|c|}
\hline & & \multicolumn{6}{|c|}{ Ilustracija } & \multirow{2}{*}{\multicolumn{2}{|c|}{$\chi^{2}-$ preizkus }} \\
\hline & & \multicolumn{2}{|c|}{ A - L. Osterc } & \multicolumn{2}{|c|}{ B - M. Manček } & \multicolumn{2}{|c|}{ skupaj } & & \\
\hline & & $f$ & $\mathrm{f} \%$ & $f$ & $\mathrm{f} \%$ & $f$ & $f \%$ & $\chi^{2}$ & $\mathrm{P}$ \\
\hline \multirow{2}{*}{$\begin{array}{l}\text { Hišni hrup nastane } \\
\text { zaradi prepiranja. }\end{array}$} & YES & 14 & 8.3 & 92 & 69.7 & 106 & 35.2 & \multirow{2}{*}{122.520} & \multirow{2}{*}{0.000} \\
\hline & NO & 155 & 91.7 & 40 & 30.3 & 195 & 64.8 & & \\
\hline \multirow{2}{*}{$\begin{array}{l}\text { Zvoki v stanovanju } \\
\text { (posoda, domače živali } \\
\text { ipd.) }\end{array}$} & YES & 156 & 92.3 & 66 & 50.0 & 222 & 73.8 & \multirow{2}{*}{68.531} & \multirow{2}{*}{0.000} \\
\hline & & 13 & 7.7 & 66 & 50.0 & 79 & 26.2 & & \\
\hline
\end{tabular}

Zanimalo nas je tudi, v kakšnem okolju živi Pedenjped. Najpogostejši odgovor vprašanih je bil, da živi Pedenjped v okolju, kjer ni miru, najmanjkrat pa so študentje zapisali, da se, zaradi družinskih razmer zateče v svoj svet. Med odgovori so se pojavile statistični značilne razlike (tabela 3 ).

Tabela 3: Opis okolja

\begin{tabular}{|c|c|c|c|c|c|c|c|c|c|}
\hline & & \multicolumn{6}{|c|}{ Ilustracija } & \multirow{2}{*}{\multicolumn{2}{|c|}{$\chi^{2}-$ preizkus }} \\
\hline & & \multicolumn{2}{|c|}{ A - L. Osterc } & \multicolumn{2}{|c|}{ B - M. Manček } & \multicolumn{2}{|c|}{ skupaj } & & \\
\hline & & $f$ & $\mathrm{f} \%$ & $f$ & $f \%$ & $f$ & $f \%$ & $\chi^{2}$ & $\mathrm{P}$ \\
\hline \multirow{2}{*}{$\begin{array}{l}\text { Okolje, v katerem se } \\
\text { starša prepirata. }\end{array}$} & YES & 5 & 3.0 & 39 & 29.5 & 44 & 14.6 & \multirow{2}{*}{41.974} & \multirow{2}{*}{0.000} \\
\hline & NO & 164 & 97.0 & 93 & 70.5 & 257 & 85.4 & & \\
\hline \multirow{2}{*}{ Neurejeno okolje. } & YES & 6 & 3.6 & 41 & 31.1 & 47 & 15.6 & \multirow{2}{*}{42.568} & \multirow{2}{*}{0.000} \\
\hline & NO & 163 & 96.4 & 91 & 68.9 & 254 & 84.4 & & \\
\hline \multirow{2}{*}{$\begin{array}{l}\text { Okolje, kjer ni miru in je } \\
\text { glasno. }\end{array}$} & YES & 50 & 29.6 & 59 & 44.7 & 109 & 36.2 & \multirow{2}{*}{7.326} & \multirow{2}{*}{0.007} \\
\hline & NO & 119 & 70.4 & 73 & 55.3 & 192 & 63.8 & & \\
\hline \multirow{2}{*}{$\begin{array}{l}\text { Okolje, kjer prevladu- } \\
\text { jejo slabi odnosi, brez } \\
\text { starševske ljubezni. }\end{array}$} & YES & 14 & 8.3 & 37 & 28.0 & 51 & 16.9 & \multirow{2}{*}{20.535} & \multirow{2}{*}{0.000} \\
\hline & NO & 155 & 91.7 & 95 & 72.0 & 250 & 83.1 & & \\
\hline \multirow{2}{*}{$\begin{array}{l}\text { Prijazno in spodbudno } \\
\text { okolje. }\end{array}$} & YES & 61 & 36.1 & 0 & 0.0 & 61 & 20.3 & \multirow{2}{*}{59.755} & \multirow{2}{*}{0.000} \\
\hline & NO & 108 & 63.9 & 132 & 100.0 & 240 & 79.7 & & \\
\hline \multirow{2}{*}{$\begin{array}{l}\text { Svoj svet, v katerega } \\
\text { se Pedenjped zateče } \\
\text { zaradi družinskih } \\
\text { razmer. }\end{array}$} & YES & 2 & 1.2 & 17 & 8.3 & 19 & 6.3 & \multirow[b]{2}{*}{17.142} & \multirow[b]{2}{*}{0.000} \\
\hline & & 167 & 98.8 & 115 & 123.7 & 282 & 93.7 & & \\
\hline
\end{tabular}

\section{Diskusija}

Glede na rezultate raziskave lahko sklepamo, da so se pri opisovanju značaja anketirani naslonili predvsem na besedilo in ne na ilustracijo, saj se 
odgovori med skupinama anketiranih statistično značilno ne razlikujejo. Pri tem pa je potrebno omeniti tudi druge pesmi o Pedenjpedu, saj so podoba in lastnosti, ki mu jih pripisujejo vprašani, opisane skozi celoten avtorjev opus o Pedenjpedu, kakor jih je ilustriral Marjan Manček. Na Pedenjpedovo zunanjost so vezana dečkova oblačila in obutev, skuštrani lasje, štrleča ušesa, jamice na licu, rad je potico, slaščice in sladoled. Da gre res za majhnega dečka, smemo sklepati iz njegovega vedenja: vrta si po nosu, tega si ne obriše sam, se igra domišljijske igre, se huduje na svojo podobo v ogledalu (ne prepozna se), riše po stenah, brez posluha igra na piščal. Posledično je njegova hudomušnost in razigranost včasih moteča in jo slabo odnese, npr. oče ga pošlje za kazen v posteljo, ker je porisal stene, boli ga trebuh, ker je pojedel preveč sladkarij, zbode se na kaktusu, ki ga nepazljivo zaliva. Grafenauer izpostavlja torej tiste lastnosti, dejavnosti in podobo, ki jo pripisujemo majhnemu otroku.

Raziskava je pokazala, da ima pri opisovanju videza vodilno vlogo slika oz. ilustracija, saj se je med opisi anketiranih pokazala statistično značilna razlika glede na opazovano ilustracijo. Pri Mančkovem Pedenjpedu (B) so študentje pogosteje opazili velika rdeča očala, ki so na ilustraciji upodobljena tako, da jih bralec/gledalec takoj opazi (velikost očal glede na glavo, prostorski plani, zorni kot). Več kot polovica študentov, ki so opazovali Mančkovega Pedenjepeda, je zapisala, da je je to majhen deček ali otrok. Odgovor ni nepričakovan glede na sorazmerje glave in trupa, ki nakazuje proporce otroka. Odgovor študentov pa je še bolj razumljiv, če privzamemo, da študentje lik Pedenjpeda poznajo tudi iz drugih pesmi in ilustracij. Več kot desetina študentov je opazila velika ali štrleča Pedenjpedova ušesa, ki jih Grafenauer omenja v pesmi Pedenjped (1966, str. 6): »Uhlja kot dva sprta strica/ muhasto štrlita v svet.« Grafenauerjev Pedenjped je kanonski lik slovenske mladinske književnosti, ki ga spoznajo otroci na Slovenskem večinoma že v vrtcu, najpozneje pa v prvem triletju osnovne šole, kjer je poudarek predvsem na pesmih o Pedenjpedu. ${ }^{25}$ Anketirana populacija študentov je stara med 19 in 21 let, kar pomeni, da so v osnovni šoli gotovo obravnavali Pedenjpeda z Mančkovimi ilustracijami, saj so le-te ponatisnjene tudi v berilih. ${ }^{26}$

Lik Pedenjpeda, ki ga je ustvarila Lidija Osterc, se od Mančkovega zelo razlikuje, zato je razumljivo, da so pri opisovanju videza podali študentje drugačne opise. Opisovali so pričesko, hlače in nogavice. Figura je upodobljena

25 V Učnem načrtu Slovenščina (http://www.mizs.gov.si/fileadmin/mizs.gov.si/pageuploads/ podrocje/os/prenovljeni_UN/UN_slovenscina_OS.pdf, str. 21-22, pridobljeno 15. 3. 2015) so za drugi razred OŠ predlagane za obravnavo naslednje pesmi: Dvojčka, Sladkosned, Trd oreh. Ob pridobivanju literarnovednega znanja je Niko Grafenauer naveden kot obravnavani avtor za področje mladinske poezije.

26 Ob tem lahko ugotovimo, da je v slovenskih knjižnicah dostopnih veliko več izvodov slikanice $\mathrm{z}$ Mančkovimi ilustracijami, kakor pa obeh izdaj Pedenjpeda z ilustracijami Lidije Osterc. 
celopostavno in pokončno, zato je lažje opaziti podrobnosti. Hkrati pa je lik Pedenjpeda $\mathrm{z}$ vidika sodobnega časa nenavaden in poseben, saj njegova oblačila pripadajo času nastanka dela (torej preteklosti). Hkrati lahko opazimo, da je je ilustratorka ustvarila stilizirano podobo dečka, čigar značilnosti najdemo tudi $\mathrm{v}$ drugih avtoričinih ilustracijah, in so sestavni del njene likovne govorice (npr. Srečko Kosovel, Naša bela mačica, 1969). Majhen delež študentov je Pedenjpedu pripisal neurejenost, opazili so tudi suho postavo. Prav tako nihče ni napisal, da je Pedenjeped otrok, desetina jih je celo zapisala, da je velik fant.

Ključna razlika glede na videz med obema likoma je starost Pedenjpeda. Pedenjped Marjana Mančka je otrok za 53,5 \% vprašanih in velik fant le za 27,2 \% vprašanih. Pednjeped Lidije Osterc je velik fant za 10,7 \% vprašanih, za nikogar, ki so opazovali tega, pa ni otrok ali majhen fant (o,o \%). Ker se velikost nanaša tudi na starost lika, je opažena razlika ključnega pomena pri interpretaciji pesmi. Večina vseh vprašanih namreč meni, da Pednjeped ne bere zares oziroma se samo pretvarja. Pri tem je seveda razlika, če ne zna brati velik fant ali majhen otrok. Iz dejavnosti, ki so v pesmi nakazane, da prelistava knjige, njegova glava je težka od znanja (stalna besedna zveza), natakne si očala, če ne bere pravilno, smemo sklepati, da še ne razume povsem vzročno-posledičnih zvez. Namreč če nekaj ne zna prebrati, mu tudi očala ne pomagajo, enako je z razumevanjem prebranega gradiva.

Analiza rezultatov je pokazala, da okolje, v katerem je upodobljen lik, spreminja kontekst besedila in vpliva na interpretacijo pesmi, saj se odgovori vprašanih razlikujejo glede na to, katero ilustracijo so opazovali med odgovarjanjem na zastavljena vprašanja. Pedenjeped Lidije Osterc živi v prijaznem in spodbudnem okolju, tudi v glasnem okolju, vendar vprašani hišni hrup povezujejo z zvoki iz stanovanja, npr. ropotanje posode, glasovi hišnih ljubljenčkov ipd. Pedenjeped Marjana Mančka živi (vrstni red glede na pogostost odgovorov): v okolju, kjer ni miru in je glasno, v neurejenem okolju, v okolju, kjer se starša prepirata, v okolju, kjer prevladujejo slabi odnosi in ni starševske ljubezni. Hišni hrup, ki ga omenja besedilo pa je v odgovorih povezan s prepirom staršev in z zvoki iz stanovanja.

Interpretacija pesmi in vzročno posledične zveze dobijo ob upoštevanju ilustracije nove razsežnosti. Najbolj na interpretacijo vpliva zaznana velikost (starost) lika in okolje, v katerem se Pedenjped nahaja. V primeru, ko je lik postavljen $\mathrm{v}$ prazen prostor, je razumevanje okolja omejeno predvsem na informacije, dobljene iz besedila. Razlaga besedne zveze hišni hrup se nanaša na izkušnje bralca (predhodno poznavanje besedne zveze in lastne izkušnje). V primeru, ko je lik postavljen v okolje, ki ga besedilo ne opisuje, je le-to pomemben del konteksta, ki ga pri interpretaciji pesmi ne moremo prezreti. Ilustracija 
Lidije Osterc ne vpliva na interpretacijo pesmi, sporočilo je enako, če interpretiramo pesem brez ilustracije ali z obravnavano ilustracijo. Marjan Manček, ki ob otroku uvede tudi okolje, na interpretacijo nesporno vpliva: ilustrator je izrisal družinsko okolje in zaradi ilustracije pridamo besedni zvezi hišni hrup pomen prepira. Zunanja podoba Mančkovega Pedenjpeda je z leti postala nesporno povezana $z$ literarnim likom, torej je postala sama po sebi prepoznaven znak kanonskega literarnega junaka.

Ugotovimo lahko, da moramo k branju ilustrirane pesmi, in seveda tudi drugih ilustriranih besedil, pristopati celostno. To pomeni, da je treba enakovredno brati besedila in ilustracije. Predvsem je celostno branje pomembno v primerih, ko gre za tip interakcije, kjer slika dopolni besedilo. Frank Serafini (2011, str. 346) je oblikoval vprašanja, s katerimi lahko učitelj učence usmerja pri analiziranju zgradbe likovnega dela v multimodalnem besedilu, npr. Katere barve so dominantne?, Kako učinkujejo nate kot na bralca?, V kaj te želi umetnik usmeriti skozi vodilne linije, barve, kontrast, geste in svetlost?

Študentje razrednega pouka in predšolske vzgoje $\mathrm{v}$ času študija dobijo ustrezna znanja s področja književnosti (osnove literarne teorije in literarne zgodovine, spoznavanje zvrsti, vrst in žanrov mladinske književnosti, branje kanonskih in sodobnih mladinskih besedil, analiza ter interpretacija le-teh) in likovnega izražanja (osnove likovne teorije, teoretično in praktično znanje o likovnih tehnikah in njihovih izraznih možnostih). Lahko bi rekli, da pridobijo vsa potrebna znanja za celostno branje slikanic in ilustriranih knjig. Težava se pojavi pri medpredmetnem povezovanju: kako torej usposobiti študente, da bodo presegli posamezno področje in pristopili k načrtovanju in realizaciji celostnega branja ilustriranih besedil. Učenci bodo doživeli interakcijo med besedilom in ilustracijo le, če jih bo učitelj oz. vzgojitelj usmerjal z vprašanji, ki spodbujajo raziskovanje, iskanje odgovorov v besedilu in ilustraciji, prepoznavanje izraznih možnosti likovnih materialov in tehnik, občutljivost za kompozicijo, podajanje informiranih odgovorov (učenci trditve podkrepijo $\mathrm{z}$ informacijo iz besedila in/ali iz ilustracije). Razvijanje tovrstnega branja bo gotovo vplivalo tudi na vizualno pismenost otrok. Vizualna pismenost je, kot jo opredelijo Vasquez, Troutman in Comer (2010, str. 2) »/.../ sposobnost (a) branja in interpretiranja vizualnih podob in (b) prenašanja informacij s pomočjo vizualnih reprezentacij «. Celostno branje ilustriranih besedil se kaže kot smiselna pot $\mathrm{k}$ boljši vizualni pismenosti učencev, zato so nadaljnje raziskave celostnega branja nujnost. 


\section{Viri}

Grafenauer, N. (1966). Pedenjped. Ilustrirala Lidija Osterc. Ljubljana: Mladinska knjiga.

Grafenauer, N. (1979). Pedenjped. Ilustriral Marjan Manček. Ljubljana: Mladinska knjiga (Zbirka

Velike slikanice).

\section{Literatura}

Doonan, J. (1993). Looking at pictures in picture books. Lockwood, Station Road, Woodchester:

Thimble Press.

Haramija, D., \& Batič, J. (2013). Poetika slikanice. Murska Sobota: Franc-Franc.

Haramija, D., \& Saksida, I. (2013). Metodologija interpretacije mladinske književnosti na

Slovenskem. Slavistična revija, 61(1), 181-193.

Hosack Janes, K. (2014). Using the Visual Arts for Cross-curricular Teaching and Learning: Imagiantive ideas for primary school. London and New York: Routledge, Taylor\&Francis Group.

Kobe, M. (1996). Slovenska mladinska književnost. V Slovenska mladinska književnost in ilustracija (str. 3-7). Ljubljana: Slovenska sekcija IBBY.

Kosovel, S. (1969). Naša bela mačica. Ilustrirala Lidija Osterc. Ljubljana: Mladinska knjiga (Zbirka Čebelica).

Nikolajeva, M. (2003). Verbalno in vizualno: slikanica kot medij. Otrok in knjiga, 58, 5-26.

Nodelman, P. (1988). Words about pictures. Athens and London: The University of Georgia Press.

Pavček, T. (2012). Juri Muri v Afriki: o fantu, ki se ni maral umivati. Ilustriral Damijan Stepančič. Dob pri Domžalah: Miš.

Prap, L. (2008). Kam gredo sanje. Ljubljana: Mladinska knjiga (Zbirka Žlabudron).

Saksida, I. (2006). Sodobna slovenska mladinska poezija. V M. Hladnik (ur.), Preseganje meje:

zbornik Slavističnega društva Slovenije 17 (str. 267-279). Ljubljana: Slavistično društvo Slovenije.

Serafini, F. (2011). Expanding Perspectives for Comprehending Visual Images in Multimodal Texts.

Journal of Adolescent \& Adoult Literacy, 54(5), 342-350.

Sipe, L. R. (1998). How Picture Books Work: A Semiotically Framed Theory of text-Picture

Relationships. Children's Literature in Education, 29(2), 97-108.

Vasquez, J. A., Troutman, F., \& Comer, M. W. (2010). Developing Visual Literacy in Science, K-8.

Arlington, VA: NSTA Press, National Science teachers Association. 